\title{
PENGARUH MODEL PEMBELAJARAN INKUIRI TERBIMBING TERHADAP HASIL DAN KETUNTASAN BELAJAR BIOLOGI PADA SISWA SMA NEGERI I BONJOL KABUPATEN PASAMAN
}

\author{
Yendrita $^{1}$, Khaharman ${ }^{2}$ \\ Prodi Pendidikan Biologi STKIP Yayasan Abdi Pendidikan \\ yen29drita@gmail.com
}

\begin{abstract}
The learning process may provide more satisfying learning outcomes, if it is carried out with learning that provides opportunities for students to find their own concepts from what they learn. However, the learning process is still often carried out using an expository approach through the lecture method. One of the efforts that teachers can do in order to improve learning is to apply the Inquiry learning model. This study aims to see the effect of using the inquiry learning model in biology learning on the learning outcomes of class X students of SMA N 1 Bonjol. Research type is quasi-experimental. The population in this study were students of class X SMA $N 1$ Bonjol. Sampling was done by purposive random sampling, which was chosen to be the experimental class was X2, while the control class was X8. The instrument used was an objective test. The data analysis technique used is the $t^{\prime}$ test. From the results of data analysis obtained t'count $=6,60 \quad t_{1}=1,70 \quad t_{2}=$ 1,70. So that the proposed hypothesis is accepted at the $95 \%$ confidence level. Thus, it can be concluded that there is a significant influence in the use of the inquiry learning model on the biology learning outcomes of students in class X SMA N 1 Bonjol, Pasaman Regency, 2016/2017 academic year.
\end{abstract}

Key Word: Inquiry Learning, Biology Study Results

\begin{abstract}
Abstrak
Proses pembelajaran dapat memberikan hasil belajar yang lebih memuaskan, jika dilakukan dengan pembelajaran yang memberikan kesempatan kepada siswa untuk menemukan sendiri konsep dari apa yang dipelajarinya. Namun demikian, proses pembelajaran masih ada yang dilakukan dengan menggunakan pendekatan ekspositori melalui metode ceramah. Salah satu upaya yang dapat dilakukan guru dalam rangka meningkatkan pembelajaran adalah dengan menerapkan model pembelajaran Inkuiri. Penelitian ini bertujuan untuk melihat pengaruh penggunaan model pembelajaran inkuiri dalam pembelajaran biologi terhadap hasil belajar siswa kelas X SMA N 1 Bonjol. Jenis penelitian adalah quasi eksperiment. Populasi dalam penelitian ini adalah siswa kelas X SMA N 1 Bonjol. Pengambilan sampel dilakukan secara purposive random sampling, yang dipilih menjadi kelas eksperimen adalah X2, sedangkan kelas kontrol adalah X8. Instrumen yang digunakan adalah tes objektif. Teknik analisis data yang digunakan adalah uji $t$. Dari hasil analisis data diperoleh t'hitung $=6,60 t_{1}=1,70 t_{2}=1,70$. Sehingga hipotesis yang diajukan diterima pada tingkat kepercayaan 95\%. Dengan demikian, dapat disimpulkan bahwa terdapat pengaruh yang signifikan dari penggunaan model pembelajaran inkuiri terhadap hasil belajar biologi siswa kelas X SMA N 1 Bonjol Kabupaten Pasaman Tahun Pelajaran 2016/2017.
\end{abstract}

Kata Kunci : Pembelajaran Inkuiri terbimbing, Hasil Belajar biologi 


\section{PENDAHULUAN}

Sesuai dengan tuntutan paradigma baru pendidikan dan pembelajaran sains, dimana pembelajaran sains hendaklah dilaksanakan sesuai dengan pendekatan konstruktivis, dimana siswa diharapkan dapat menyusun dan menemukan sendiri konsep dari materi yang sedang dipelajarinya. Biologi adalah ilmu yang mempelajaran tentang seluk-beluk makhluk hidup, Objek kajian biologi berupa benda-benda mikro dan benda makro. Mata pelajaran biologi merupakan bidang studi yang mempelajari berbagai macam struktur, proses, dan fungsi dari makhluk hidup. Proses pembelajaran biologi sangat memungkinkan jika dilaksanakan dengan pendekatan konstruktivis, Namun, pada saat ini masih banyak guru yang sering menggunakan metode ceramah dengan pendekatan ekspositori yang mana guru menyampaikan materi secara verbal kepada siswa dan menjadikan guru sebagai pusat informasi.

Salah satu sekolah yang masih menggunakan pendekatan ekspositori dalam proses pembelajaran biologi pada tahun akademik 2016/2017 adalah pembelajaran biologi pada kelas X di SMAN 1 Bonjol. Dimana pembelajaran masih didominasi oleh metode ceramah. Hal ini mungkin salah satu penyebab rendahnya hasil belajar dan ketuntasan belajar siswa, dimana KKM yang dituntut pada bidang studi biologi di kelas X SMA N 1 Bonjol adalah 75 sedangkan rata-rata nilai ujian biologi siswa dari 9 kelas, hanya 2 kelas yang mendapatkan ketuntasan klasikal. Hal ini dapat dilihat dari rata-rata nilai UH semester 2 kelas X SMA N 1 Bonjol, disamping itu, dalam proses pembelajaran biologi siswa tidak bersemangat, mereka hanya paham disaat proses pembelajaran saja, tetapi setelah diberi kuis, para siswa tidak bisa menjawab dengan benar, seakan - akan konsep tersebut tidak tinggal di memori mereka.

Salah satu alternatif yang mungkin bisa menaikkan hasil belajar dan ketuntasan belajar biologi pada siswa kelas X SMAN I bonjol ini adalah penggunaan model pembelajaran Inkuiri terbimbing, dimana model pembelajaran inkuiri juga belum pernah diterapkan dalam pembelajaran biologi di SMA N I Bonjol.

Model pembelajaran Inkuiri, menuntut siswa menemukan sendiri konsep dari pokok permasalahan, dengan diterapkannya model pembelajaran Inkuiri ini diharapkan dapat meningkatkan hasil belajar siswa, karena model pembelajaran inkuiri adalah kegiatan pembelajaran yang memfasilitasi peserta didik untuk bertanya, melakukan penyelidikan secara mandiri untuk menemukan apa yang mereka butuhkan, sebagaimana yang dikatakan oleh (Priansa dan Doni 2017 : 258) bahwa inkuiri learning adalah " Model pembelajaran yang mendorong peserta didik untuk mencari dan menemukan sendiri pengetahuan yang mereka butuhkan lewat pertanyaan atau penyelidikan." Sehubungan dengan hai ini besar kemungkinan konsep yang diperoleh siswa secara mandiri akan berbekas dalam memorinya. Apabila ditanya mereka akan mudah mengingat kembali.

Selain hal diatas, pembelajaran inkuiri akan mengembangkan karakter siswa, Purniadi (2017) menyimpulkan bahwa" model pembelajaran inkuiri dapat mengembangkan karakter, kerja sama, rasa ingin tahu dan komunikatif siswa". Disamping mengembangkan karakter, kerja sama dan rasa ingin tahu, pembelajaran inkuiri juga dapat meningkatkan hasil belajar dan ketuntasan belajar IPA biologi (Mariani Natalina, Imam Mahadi, Anisa Carolina Suzane: 2013) Berdasarkan hal diatas, maka diharapkan pelaksanaan model pembelajaran 
inkuiri dapat meninggkatkan hasil belajar dan ketuntatasan belajar biologi pada siswa kelas X SMA N I Bonjol tahun pelajaran 2016/2017.

Berdasarkan latar belakang masalah diatas, maka tujuan penelitian ini adalah :

1. Untuk mengetahui apakah ada pengaruh yang signifikan dari penggunaan Model Pembelajaran Inkuiri Dalam Pembelajaran Biologi terhadap hasil belajar siswa pada kelas X SMA N 1 Bonjol Kabupaten Pasaman Tahun Ajaran 2016/2017.

2. Untuk melihat perbedaan ketuntasan dalam pembelajaran biologi pada siswa kelas X SMA N I Bonjol, antara pembelajaran yang dilaksanakan dengan inkuiri terbimbing dan pembelajaran konvensional.

\section{METODE PENELITIAN}

Jenis penelitian ini adalah penelitian quasi eksperiment, karena tidak semua variabel bisa dikontrol. Rancangan penelitian ini adalah Randomized Subjects Postsest-Only Control Group Design, dengan dua kelas sampel, yaitu kelas eksperimen, yang diberi perlakukan, yaitu pembelajaran dilaksanakan dengan Inqury Learning dan kelas kontrol tanpa adanya perlakuan, dimana pembelajaran dilaksanakan dengan ceramah. Diakhir penelitian sama - sama diberikan tes akhir, yang merupakan data dari penelitian ini. Rancangan penelitian ini dapat dilihat pada tabel 2. dibawah ini

Tabel 1 : Rancangan Penelitian

\begin{tabular}{|c|c|c|}
\hline Group & Treatment & Hasil Belajar \\
\hline Eksperimen & $\mathrm{X}$ & $\mathrm{Y} 1$ \\
\hline Kontrol & - & $\mathrm{Y} 2$ \\
\hline
\end{tabular}

Sumber : Sukardi (2013)

Keterangan :

$\mathrm{X}=$ Pembelajaran dengan model pembelajaran Inkuiri

$\mathrm{Y} 1=$ Tes akhir di kelas eksperimen

$\mathrm{Y} 2=$ Tes akhir di kelas kontrol

Populasi penelitian ini adalah siswa kelas X IPA SMA N.I Bonjol yang berjumlah 9 Kelas. Pengambilan sampel dilakukan dengan Teknik purposiv random sampling, yaitu pengambilan sampel dengan teknik pertimbangan tertentu. Pertimbangan yang digunakan adalah nilai Ujian Harian Biologi Semester 2. yang memiliki rata - rata kelas yang rendah dan mendekati sama, memiliki ketuntasan dan ketidak tuntasan yang hampir sama, serta kelas tersebut diajar oleh guru yang sama, maka terpilihlah kelas X6 sebagai kelas kontrol dengan nilai rata - rata UH 57,03 dan ketuntasan klasikal 3,33\% dan kelas X7 sebagai kelas eksperimen dengan nilai rata- rata UH 58,88 dan ketuntasan klasikal 3,70\%. 
Instrumen penelitian ini berupa seperangkat tes, yang sebelumnya telah diuji cobakan dan dianalisis validitas tes, Reliabelitas tes ,daya beda dan indeks kesukarannya. Data dianalisis dengan t’ uji pihak kanan, dengan kriteria, diterima H1 jika:

$$
\begin{aligned}
& \mathrm{t}_{\text {hitung }}>\frac{\mathrm{w}_{1} \mathrm{t}_{1}+\mathrm{w}_{2} \mathrm{t}_{2}}{\mathrm{w}_{1}+\mathrm{w}_{2}} \\
& \mathrm{w}_{1}=\mathrm{s}_{1}{ }^{2} / \mathrm{n}_{1} ; \quad \mathrm{w}_{2}=\mathrm{s}_{2}{ }^{2} / \mathrm{n}_{2} \\
& \text { dan } \mathrm{t}_{1}=\mathrm{t}(1-\mathrm{a}),\left(\mathrm{n}_{1}-1\right) \quad \mathrm{t}_{2}=\mathrm{t}(1-\mathrm{a}),\left(\mathrm{n}_{2}-1\right) \text { Dengan } \mathrm{a}=0,05 \\
& \text { Sudjana (1996) }
\end{aligned}
$$

Selanjutnya untuk melihat ketuntatasan belajar siswa digunakan rumus untuk ketuntasan sebagai berikut:

1. Ketuntasan individu

$(\mathrm{KI})=$ Jika proposi jawaban siswa benar atau nilai $\geq \mathrm{KKM}$

Ket;

$\mathrm{KI}=$ ketuntasan individu

$\mathrm{KKM}=$ kriteria ketuntasan minimal

2. Ketuntasan klasikal

$(\mathrm{KK})=\frac{\mathrm{n} \geq \mathrm{KKM}}{\mathrm{N}} \times 100 \%$

Ket:

$\mathrm{KK} \quad=$ ketuntasan klasikal

$\mathrm{n} \quad$ = banyaknya siswa yang mendapatkan nilai diatas KKM

$\mathrm{N} \quad=$ jumlah seluruh peserta tes

$\mathrm{KKM}=$ Kriteria ketuntasan minimal

\section{HASIL DAN PEMBAHASAN}

\section{Hasil}

Data dari kedua kelas sampel dapat dilihat pada tabel 2.di bawah ini:

Tabel 2. Jumlah Sampel,Nilai Rata-Rata,Standar dan Variansi tes Akhir Pada Kelas sampel

\begin{tabular}{|l|c|c|c|c|}
\hline \multicolumn{1}{|c|}{ Kelas } & $\mathbf{n}$ & $\underline{\bar{X}}$ & $\mathbf{S}$ & $\mathbf{S}^{2}$ \\
\hline Eksperimen & 28 & 84,00 & 10,53 & 110,88 \\
\hline Kontrol & 30 & 59,59 & 17,30 & 299,29 \\
\hline
\end{tabular}

Keterangan :

$\begin{array}{ll}\mathrm{n} & \text { : Jumlah siswa } \\ \bar{X} & : \text { Nilai Rata-rata } \\ \mathrm{S} & : \text { Standar Deviasi } \\ \mathrm{S}^{2} & : \text { Variansi }\end{array}$

Sebelum data dianalisis, maka terlebih dahulu telah dilakukan persyaratan untuk uji t:

\section{Uji Normalitas}

Hasil Uji Lilifors bertujuan untuk melihat apakah data pada kedua kelas sampel berdistribusi normal atau tidak. Uji normalitas dilakukan dengan menggunakan rumus yang dikemukakan Sudjana (2005 ). Ternyata sebaran data pada kedua kelas sampel berdistribusi secara normal. Hasil uji Normalitas pada kedua kelas sampel dikemukakan pada tabel 3 berikut ini: 
Tabel 3 :Hasil Uji Normalitas Pada kedua Kelas Sampel

\begin{tabular}{|l|c|c|c|c|c|}
\hline \multicolumn{1}{|c|}{ Kelas } & $\mathrm{n}$ & $\mathrm{a}$ & $\mathrm{L}_{0}$ & $\mathrm{~L}_{\mathrm{t}}$ & Analisis \\
\hline Eksperimen & 28 & 0,05 & 0,0868 & 0,161 & $\mathrm{~L}_{0}<\mathrm{L}_{\mathrm{t}}$ (Normal) \\
\hline Kontrol & 30 & 0,05 & 0,0890 & 0,161 & $\mathrm{~L}_{0}<\mathrm{L}_{\mathrm{t}}$ (Normal) \\
\hline
\end{tabular}

\section{Uji Homogenitas}

Hasil uji Homogenitas bertujuan untuk mengetahui apakah data pada kedua sampel mempunyai varians yang homogen atau tidak. Hasil uji homogenitas didapatkan $\quad F_{\text {hitung }}>F_{\text {tabel }}$, berarti kedua kelas sampel mempunyai variansi yang tidak homogen pada $a=0.05$, hal ini dapat dilihat pada tabel 4 di bawah ini .

Tabel 4 : Hasil Uji Homogenitas

\begin{tabular}{|l|c|c|c|c|c|c|}
\hline \multicolumn{1}{|c|}{ Kelas } & $\mathrm{n}$ & Nilai & $\mathrm{S}$ & $\mathrm{S}^{2}$ & $\mathrm{~F}$ Hitung & F tabel \\
\cline { 1 - 5 } Eksperimen & 28 & 84,00 & 10,53 & 110,88 & 2,69 & 1,85 \\
\cline { 1 - 5 } Kontrol & 30 & 59,37 & 17,30 & 299,29 & & \\
\hline
\end{tabular}

\section{Uji Hipotesis}

Hipotesis diuji dengan t' uji pihak kanan. karena data berdistribusi normal tetapi mempunyai varians yang tidak homogen.

hasil analisis data menunjukkan dapat dilihat pada tabel 5 dibawah ini.

Tabel 5 : Hasil Analisis Data

\begin{tabular}{|c|c|c|c|c|c|}
\hline $\mathbf{t}^{\mathbf{1}}$ & $\mathbf{w}_{\mathbf{1}}$ & $\mathbf{w}_{\mathbf{2}}$ & $\begin{array}{c}\mathbf{t}_{\mathbf{1}} \\
(\mathbf{1}-\mathbf{a}) \mathbf{2 7}\end{array}$ & $\begin{array}{c}\mathbf{t}_{\mathbf{2}} \\
(\mathbf{1}-\mathbf{a}) \mathbf{2 9}\end{array}$ & $\frac{\mathbf{w}_{\mathbf{1}} \cdot \mathbf{t}_{\mathbf{1}}+\mathbf{w}_{\mathbf{2}} . \mathbf{t}_{\mathbf{2}}}{\mathbf{w}_{\mathbf{1}}+\mathbf{w}_{\mathbf{2}}}$ \\
\hline 6,6 & 3,96 & 9,98 & 1,70 & 1,70 & 1,7 \\
\hline
\end{tabular}

Pada tabel 5. Di atas terlihat bahwa $t^{1} \geq \underline{w_{1} . t_{1}+w_{2} . t_{2}}$, Hipotesis di terima pada taraf kepercayaan $95 \%$. $\mathrm{W}_{1}+\mathrm{W}_{2}$

\section{Ketuntatasan belajar siswa :}

Hasil analisis ketuntasan belajar siswa pada kedua kelas sampel dapat dilihat pada tabel 6 di bawah ini :

Tabel 6. Hasil Analisis Ketuntasan Belajar Siswa Sebelum dan Sesudah Perlakuan

\begin{tabular}{|c|c|c|c|c|c|}
\hline \multirow{2}{*}{ Kelas } & N & \multicolumn{2}{c|}{$\begin{array}{c}\text { Ketuntasan } \\
\text { Individu }\end{array}$} & \multicolumn{2}{c|}{ Ketuntasan Klasikal } \\
\cline { 3 - 6 } & & Sebelum & Setelah & Sebelum & Setelah \\
\hline Eksperimen & 28 & 1 & 25 & $3,6 \%$ & $89,3 \%$ \\
\hline Kontrol & 30 & 1 & 6 & $3,3 \%$ & $20 \%$ \\
\hline
\end{tabular}




\section{PEMBAHASAN}

Hasil penelitian menunjukkan bahwa nilai rata - rata kelas eksperimen yang pembelajaranya dilakukan dengan inkuiri lebih tinggi secara signifikan dibandingkan dengan nilai rata - rata kelas kontrol yang pembelajarannya dilakukan dengan ceramah, hal ini dtunjukkan dengan hasil analisis data yang dilakukan dengan uji $\quad t^{1} \geq \underline{w}_{1} . t_{1}+w_{2} . t_{2} \quad$ dengan signifikansi $=0,05$.

$$
\mathrm{W}_{1}+\mathrm{W}_{2}
$$

Begitu pula dengan ketuntasan belajar biologi di kelas eksperimen juga lebih tinggi dibandingkan dengan kelas kontrol. hal ini memberi pengertian bahwa pembelajaran inkuiri terbibing lebih unggul dibandingkan dengan pembelajaran konvensional. Tingginya hasil dan ketuntasan belajar siswa di kelas eksperimen disebabkan karena pembelajaran inkuiri merupakan aplikasi dari pendekatan yang berbasis student centered. Salah satu pendekatan yang berbasis student centered adalah pendekatan konstruktivis. Dalam pembelajaran konstruktivis, siswa akan menyusun sendiri konsep- konsep yang berhubungan dengan materi yang sedang dipelajari. Sebagaimana yang dikemukakan oleh M.Adnan (2002:2) bahwa "Ciri khas pemebelajaran konstruktivisini yaitu kreativitas dan keterlibatan siswa dalam proses dan upaya belajar sesuai dengan kemampuan, pengetahuan awal dan gaya belajar masing - masing siswa".

Perbedaan hasil belajar ini, disebabkan karena pembelajaran inkuiri ini memang pembelajran yang dapat memberikan pemahaman yang mendalam terhadap suatu materi, karena pembelajaran tersebut menuntut siswa sebagai pusat kegiatan pembelajaran, sehingga siswa bukan hanya mendapatkan hasil yang tinggi tetapi banyak hal yang akan diperoleh siswa dalam pelaksanaan pembelajaran inkuiri terbimbing itu. Pada abad 21 ini yang diperlukan bukan hanya hasil belajar yang tinggi saja, tetapi yang diharapkan adalah lulusan yang mempunyai aktifitas yang tinggi, inovatif, mempunyai kreatifitas, kritis dan mampu berkolaborasi. Hal ini akan dapat terujut jika siswa telah dilatih mulai dari proses pembelajaran pada setiap mata pelajaran dan tidak terkecuali pada pembelajaran biologi. Pembelajaran yang dapat mewujutkan hal di atas diantaranya adalah pembelajaran yang melatih siswa untuk menemukan suatu konsep dan berlatih dalam menyelesaikan suatu masalah.

Namun demikian, guru pembelajaran sains khususnya pembelajaran biologi masih banyak yang membelajaran biologi dilakukan hanya dengan metode ceramah , kalaupun ada praktet, kegiatannya hanya berfokus pada pengujian kebenaran teori - teori taedahulu.Kegiatan belajar kurang diarahkan pada bagaimana cara mengkonstruksi ide - ide atau gagasan ilmiah yang baru melalui proses inkuiri ilmiah. Dalam rangka mempersiapkan siswa untuk bisa menjalani kehidupan masa datang yang serba belum pasti dan tidak menentu, maka diharapkan guru sains mampu untuk mengembangkan pengalaman inkuiri dalam proses pembelajaran, selain itu pendidikan diharapkan sudah dapat menggeser paradigma pembelajaran sains yang lebih berorientasi teacher oriented menjadi student oriented.

Guru sains dan tidak terkecuali guru biologi masa sekarang harus mampu menyiapkan siswa untuk menjadi anggota masyarakat masa depan yang melek sains, masyarakat yang mampu berfikir tingkat tinggi, mempunyai rasa ingin tahu yang tinggi, mempunyai tenaga kerja yang profesional. Saai ini kehidupan kita penuh dengan kemajuan teknologi yang dilandasi oleh inkuiri ilmiah. Terkait 
dengan hal ini, tidak tertutup kemungkinan, jika suatu saat nanti siswa kita sekarang akan memasuki dunia kertja dan berhadapan dengan produk - produk yang belum ada saat ini atau produk yang akan dihasilkan dari proses inkuiri.

Bardasarkan hal di atas, maka proses pembeajaran harus diarahkan untuk membimbing siswa untuk mampu menganalisis dengan kritis serta mempunyai inovatif yang tinggi dalam menghadapi masalah kehidupan yang cepat berubah, melalui sejumlah kompetensi yang harus dimiliki, oleh sebab itu diharapkan melalui pembelajaran di kelas siswa terbiasa untuk menyusun dan menemukan suatu konsep melalui observasi terhadap suatu objek yang dipelajari. Terkait dengan hal di atas, maka guru biologi yang profesional bertanggung jawab untuk memfasilitasi siswa untuk melaksanakan pembelajaran dengan menggunakan model inkuiri. Hal ini tentu akan mempengaruhi kehidupan siswa, yang semula terbiasa menerima apa adanya yang dinformasikan guru, menjadi siswa yang mempunyai sikap aktif, kreatif, inovatif dan bisa berkolaborasi dengan lingkungan.

Pembelajaran yang relevan dengan tantangan pradigma pendidikan baru adalah pembelajaran yang memperdayakan siswa untuk mempunyai kemampuan berfikir kreatif, mampu menyelesaikan masalah, membudayakan sikap, mandiri, bertanggung jawab, demokratis, jujur dan bermoral. Salah bentuk pembelajaran yang cocock dengan harapan tersebut adalah model pembelajaran inkuri terbimbing. Model pembelajaran inkuiri terbimbing, merupakan model pembelajaran yang bisa membuat peserta didik berpartisipasi aktif dalam proses pembelajaran. Model pembelajaran Inkuiri menuntut setiap anggota kelas untuk dapat menemukan sendiri konsep dari materi yang sedang dipalajari, dengan demikian peserta didik lebih memahami materi secara mendalam, selain itu, pembelajaran inkuiri juga melatih peserta didik untuk berfikir kritis, inovatif dan bisa berkolaborasi dengan teman. Inkuiri menuntut siswa untuk memahami dari konsep secara mandiri dan hal ini membuat konsep tersebut tersimpan dalam memori peserta didik secara utuh dan rapi, serta sulit untuk dilupakan, karena model pembelajaran inkuiri mempunyai tujuan untuk mengembangkan kemampuan berpikir secara sistematik, logis, dan kritis untuk mengembangkan kamampuan intelektual.

Model Inkuiri merupakan salah satu aplikasi pradigma baru pembelajaran, Pembelajaran dengan model inkuiri bukan hanya mementingkan hasil, tetapi kebermaknaan dari apa yang diperoleh oleh peserta didik, sehingga konsep yang diperoleh secara mandiri itu akan berguna dalam kehidupannya. Sebagaimana yang disampaikan oleh (Latief 2002) bahwa Keberhasilan dalam belajar menurut pradigma baru dapat diukur dengan kemuauan dan kemampuan siswa dalam belajar dengan gaya masing - masing peserta didik, kemampuan mengorganisasikan dan kemampuan memberi makna.

Kemampuan siswa untuk mempunyai sikap aktif, kreatif, inovatif serta mempunyai pengetahuan yang bermakna akan diperoleh dari pelaksanaan pembelajaran inkuiri yang dilaksanakan melalui langkah - langkah inkuiri yang dikemukan oleh (Wina 2006 ;201) sebagai berikut:

a. Orientasi

Memberikan stimulus yang menarik bagi siswa, menciptakan kasus rasa ingin tahu siswa dan memberi bimbingan agar siswa dapat berlatih menggunakan pemikiran pada suatu masalah berdasarkan suatu masalah 
yang diberikan kepada siswa. Hal ini berfungsi untuk menimbulkan sifat aktif, inovatif dan kreatif.

b. Merumuskan masalah

Siswa diharapkan dapat memunculkan pertanyaan - pertanyaan yang menjadi dasar untuk merumuskan hipotesis, seandainya rumusan masalah belum tepat, maka guru hanya memberi pertanyaan pemancing atau pertanyaan pemandu, sampai siswa dapat menemukan rumusan masalah yang benar, dengan hal ini siswa akan terbiasa untuk menganalisa masalah dalam rangka mencari solusi pemecahannya,.

c. Mengajukan hipotesis

Pada tahap ini siswa difasilitasi dengan bahan bacaan yang dapat membantu siswa untuk merumuskan hipotesis, yang nantinya akan diuji kebenarannya. Hal ini akan melatih siswa untuk mendapatkan alternatif alternatif jawaban dari suatu masalah yang akan dihadapi dalam kehidupan dimasa yang akan datang

d. Mengumpulkan data

Pada tahap ini, siswa diharapkan untuk membaca, secara mandiri, mengumpulkan bahan- bahan dari internet, melakukan eksperimen kecil dan sabagainya. Tahap ini akan melatih siswa untuk aktif, kreatif inovatif dan kritis terhadap suatu masalah.

e. Menguji hipotesis

Pada tahap ini siswa akan diajak untuk mengorganisasikan data ke dalam tabel - tabel atau daftar, atau ringkasan yang akan mudah mereka dalam menguji kebenaran hipotesis yang telah mereka susun dilangkah sebelumnya. Langkah ini akan melatih siswa untuk mempunyai sikap kritis dan analisis srta inovatif.

f. Menyimpulkan

Pada tahap ini siswa membuat kesimpulan tentang hasil pengujian hipotesis yang telah dilakukan. Besar kemungkinan mereka akan menemukan informasi yang tidak sesuai dengan hipotesis atau sebaliknya, dari sinilah mereka akan melakukanm penyimpulan berdasarkan rasionaitas dan penelidikan ilmiah dan sesuai dengan fakta yang mereka amati pada lingkungan. Hal ini akan menjadikan siswa untuk mendapatkan pemahaman yang mendalam terhadap materi yang mereka pelajari. Dan secara konstruktif mereka akan membangun sendiri pengetahuan baru berdasarkan pengetahuan awal yang telah dimiliki sebelumnya, yang berkemungkinan belum ilmiah. Hal ini akan menjadikan siswa memperoleh pengetahuan yang penuh makna, karena pengetahuan yang didapatkan sendiri, akan berkesan di memori siswa.

Seorang guru sains yang profesional diharapkan dapat membantu siswa untuk mempelajari pengetahuan, sikap dan keterampilan - keterampilan yang dapat menjadi bekal dalam mengarungi kehidupan dan tidak memberikan konsep secara utuh. melainkan menjadikan siswa tetap sebagai pusat pembelajaran. . (Arends 2003 dalam Wahab 2003).

Model pembelajaran inkuiri memiliki ciri utama dan tujuan tertentu, ciri utama pembelajaran inkuiri terbimbing adalah penekanan pada aktifitas siswa, aktifitas siswa diarahkan untuk mencari sesuatu yang dibutuhkan, sedangkan 
tujuan pembelajaran inkuiri adalah untuk mengembangkan intelektual siswa. sebagaimana yang disampaikan oleh (Anam, Khoirul 2017 ) bahwa karakteristik pemebelajaran inkuiri adalah :

1. Menekankan aktifitas dan pusat pembelajaran terletak pada siswa secara maksimal

2. Seluruh aktivitas yang dilakaukan siswa diarahkan untuk mencari dan menemukan jawaban dari sesuatu yang dipertanyakan.

3. Mengambangkan kemampuan intelektual dan peserta didik bukan hanya dituntut untuk menguasa materi, tetapi lebih ditekankan pada bagaimana mereka dapat menggunakan potensi yang dimilikinya untuk mengembangkan pemahaman terhadap materi tertentu, dan mempersiapkan siswa dalam mengarungi kehidupan yang belum pasti.

Jauh sebelumnya (Roestiyah 2012) juga telah mengemukakan keunggulan Inquiri Learning yaitu:

1. Membentuk dan mengembangkan Self-Concept pada diri siswa, sehingga siswa dapat mengerti tentang konsep dasar dari sesuatu yang dipelajari.

2. Membantu dalam menggunakan ingatan dan transfer pada situasi proses belajar yang baru.

3. Mendorong siswa untuk berfikir dan bekerja atas inisiatif sendiri, objektif, jujur dan terbuka.

4. Mendorong siswa untuk berfikir inisiatif dan merumuskan hipotesis sendiri

5. Memberikan kepuasan intrinsik

6. Proses belajar lebih meransang

7. Dapat mengembangkan bakat atau kecakapan hidup, yang merupakan orientasi dari kurikulum 2004

sampai sampai kurikulum yang berlaku sekarang

8. Memberikan kebebasan siswa untuk belajar sendiri, hal inipun cocok dengan konsep dimana setiap siswa mempunyai potensi yang berbedabeda

9. Dapat menghindari siswa dari belajar secara tradisional.

10. Memberikan waktu pada siswa secukupnya sehingga mereka dapat mengasimilasi dan mengakomodasi informasi.

Penggunaan model pembelajaran inkuiri dapat meningkatkan keaktifan peserta didik dan memperkuat respon peserta didik dalam proses pembelajaran sehingga hasil pembelajaran menjadi meningkat. Selain itu model pembelajaran inkuiri mempunyai pengolahan sistem pembelajaran melalui cara-cara yang menuntut keterlibatan peserta secara aktif menuju belajar mandiri. Selain itu peserta didik mampu menjelaskan materi pada peserta didik lain, dengan cara mempresentasikan di depan kelas, setelah mempelajari secara mandiri, sehingga materi yang sedang dipalajari dapat dikuasai perserta didik dengan baik dan tersimpan di memorinya secara abadi.

Pemahaman yang konkrit dan kebermaknaan dari suatu konsep yang diperoleh siswa secara mandiri melalui pembelajaran inkuiri telah terlihat pada saat proses pembelajaran, dimana Selama proses pembelajaran pada kelas 
eksperimen siswa menjadi lebih aktif dari sebelumnya. Hal ini terlihat dari antusias siswa dalam mengikuti langkah-langkah yang terdapat dalam model pembejaran Inkuiri. Mereka tampak bersemangat, dan mempunyai rasa ingin tahu yang tinggi, serta antusia untuk menekukan suatu konsep baru dari apa yang sedang mereka pelajari. Dengan demikian, pada saat tes akhir dilakukan, siswa dapat menjawab soal - soal ujian dengan sempurna dan mengerjakan secara individual, sehingga memberikan ketuntasan dan hasil yang tinggi biula dibandingkan dengan kelas konvensional.

Namun demikian pembelajaran inkuiri ini bukan hanya mengutamakan hasil belajar tetapi juga menjadikan siswa kreatif, jujur dan mandiri, menghargai pendapat orang lain, terbuka terhadap gagasan baru dan kritis dalam menyelesaikan masalah (Prayitno dalam Noerhaidan; 2008). Hal ini juga terlihat pada siswa di kelas eksprimen tersebut, disaat diskusi kelas, para siswa telah bisa menghargai pendapat teman, walaupun salah menurut pandangan, mereka jujur, dan mandiri, tidak ada yang berkompromi diwaktu diadakan quis. Hal diatas juga telah terbukti pada hasil penelitian yang dilakukan oleh Mariani dkk (2013) bahwa penerapan model pembelajaran Inkuiri terbimbing dapat meningkatkan sikap ilmiah dan hasil belajar biologi siswa kelas XI IPA5 SMAN 5 Pekanbaru Tahun Ajaran 2011/2012.

Selain dapat, menumbuhkan sikap ilmiah, pada penelitian ini juga telah terbuikti bahwa pembelajaran inkuiri terbimbing juga dapat meningkatkan ketuntasan belajar, baik ketuntasan individu, maupun ketuntasan klasikal, sebagaimana yang bisa dilihat pada hasil analisa data di atas. Apabila seorang siswa mengalami ketuntasan dalam mengikuti pembelajran pada suatu materi, maka siswa tersebut akan mempunyai moptivasi yang tinggi dalam mengikuti pembelajran bnerikutnya, tentu hal ini akan memberikan pengaruh positif dalam hasil belajar siswa pada Kawasan kognitif, afektif dan psikomotor. Hal ini setara dengan kesimpulan penelitian Ni Wayan Juniati, I Wayan Widiana (2017) bahwa: model pembelajaran Inkuiri dapat meningkatkan hasil belajar dan ketuntasan siswa dalam pembelajaran IPA di kelas IV SD No. 5 Gulingan tahun pelajaran 2016/2017. Kemudian Roni dkk (2017) juga menyimpulkan penelitian nya bahwa terdapat pengaruh model pembelajaran inkuiri terbimbing dengan metode eksperimen terhadap hasil belajar fisika siswa kelas XI IPA SMAN 2 Mataram tahun pelajaran 2016/2017.

Berdasarkan uraian di atas, maka dapat dikatakan bahwa pembelajaran yang dilakukan dengan model inkuiri terbimbing memang dapat memberikan hasil yang lebih tinggi, baik dari segi keaktifan,ke kreatifan, keinovatifan dan kekritisan siswa dalam pembelajaran maupun hasil belajar pada kawasan kognitif, hal ini dapat dibuktikan dari hasil belajar yang diperoleh peserta didik pada saat diberi tes akhir pada penelitian ini, baik dari nilai rata- rata yang diperoleh siswa maupun dari ketuntasan individu serta ketuntasan klasikal yang didapatkan siswa. Hal ini sejalan dengan apa yang dikatakan ( Suryobroto 2009) bahwa pembelajaran inkuiri terbimbing mempunyai keunggulan membantu pengembangan kemampuan kogitif,afekti dan psomotorik siswa, membangkatkan gairah siswa, memberikan kesempatan kepada siswa untuk bergerak maju sesuai dengan kemampuannya, sehingga siswa termotivasi untuk belajar. Motivasi yang tinggi akan mendatangkan hasil yang maksimal. 
Sedangkan pembelajaran pada kelas kontrol dilakukan dengan pendekatan teacher centered, kegiatan siswa hanya mendengarkan guru menyampaikan materi pembelajaran, mencatat dan mengerjakan latihan. Pada saat pembelajaran berlangsung minat dan motivasi siswa dalam belajar juga masih kurang, mungkin disebabkan karena siswa hanya mengikuti pembelajaran dengan mendengarkan ceramah dari guru yang akhirnya para siswa harus mengahafal materi tanpa pengertian. Hal ini menjadikan siswa cepat bosan karena rendahnya keterlibatan siswa dalam proses pembelajaran, mereka tidak dituntut untuk kreatif, ivovatif dan kritis dalam menemukan suatu konsep dari materi yang, mereka pelajari. Para siswa tidak ada mempunyai rasa ingin tahu terhadap sesuatu yang mereka pelajari, karena mereka hanya dikondisikan untuk menerima dari guru. Pada saat tes dilakukan mereka banyak yang tidak bekerja sendiri malah mencontoh hasil pekerjaan teman yang ada didekatnya, para siswa hanya memahami materi disaat guru menyajikan di depan kelas saja, sehingga siswa mereka banyak yang tidak mengalami ketuntasan secara individu dan otomatis ketuntasan klasikal juga tidak akan tercapai, dengan demikian hasil belajar juga belum maksimal. Hal ini terbukti pada hasil penelitian ini, dimana hasil dan ketuntasan balajar biologi siswa yang pembelajarannya dilakukan dengan metode ceramah lebih rendah dibandingkan dengan pemelajaran yang dilaksanakan dengan model inkuiri terbimbing.

\section{KESIMPULAN}

Keterlibatan siswa secara aktif dalam pembelajaran inkuiri terbimbing pada kelas eksperimen, telah menjadikan siswa bersemangat dan mempunyai motivasi yang tinggi dalam mempelajari materi keanekaragaman hayati, sehingga pembelajaran inkuiri terbimbing ini telah menghasilkan nilai rata- rata dan ketuntasan siswa yang tinggi secara signifikan. Dari hasil analisis data dapat disimpulkan bahwa: Terdapat pengaruh yang signifikan dari penggunaan model pembelajaran Inkuiri terhadap hasil belajar Biologi pada siswa kelas X di SMA N 1 Bonjol Kabupaten Pasaman 2016/2017, dengan kata lain hipotesis diterima pada taraf taraf kepercayaan $95 \%$. Selain itu pembelajaran inkuiri terbimbing juga dapat meningkatkan ketuntasan individu dan ketutasan klasikal siswa pada materi keanekaragaman hayati.Dengan tingginya hasil dan ketuntasan belajar siswa, diharapkan juga dapat menumbuhkan sikap kreatif, kritis dan inovatif pada .Dengan kata lain pembelajaran inkuiri terbimbing juga akan memberikan pembelajaran yang bermakna pada siswa, kebrmaknaan suatu konsepdari materi yang sedang dipelajari,akan menjadi bekal bagi siswa dalam menyosong kehidupan dimasa yang akan datang yang didominasi oleh teknologi yang semakain maju.

Berdasarkan kesimpulan di atas, maka sangat diharapkan penggunaan model pembelajaran inkuiri ini, khususnya pada pembelajaran bidang studi biologi. Mengingat materi pembelajaran biologi sangat memungkinkan siswa untuk beraktifitas maksimal dan bisa untuk menemukan sendiri konsep dari apa sedang dipelajari, karena cakupan materi biologi itu adalah semua organisma hidup baik yang berukuran mikro maupun yang berukuran makro, yang semuanya ada di lingkungan siswa. 


\section{DAFTAR PUSTAKA}

Anam, Khoirul.2017. Pembelajaran berbasis Inkuiri,Metode dan Aplikasi.Yogyakarta : Pustaka Pelajar

Arikunto, Suharsimi. 2010. Prosedur Penelitian. Jakarta : Rineka Cipta.

Lufri. 2007. Strategi Pembelajaran Biologi. Padang :UNP Press

Latief. M.A 2002. Konstruktivis dalam Pembelajaran Bahasa Ingris, Malang: Fak Sastra.Univ.Negeri Malang

M.Adnan.2002. Belajar dan Pembelajaran Bahasa Inggris.Jakarta.Rineka Cipta

Mariani Natalina, Imam Mahadi, Anisa Carolina Suzane.2013. Penerapan Model Pembelajaran Inkuiri Terbimbing (Guided Inquiry) Untuk Menignkatkan Siklap Ilmiah dan Hasil Belajar Biologi Siswa Kelas XI IPA5 SMA Negeri Pekanbaru Tahun Ajaran 2011/2012. Prosiding Semirata FMIPA Universitas Lampung, . Pp: 83- 91

Ni Wayan Juniati, I Wayan Widiana. 2017. Penerapan Model Pembelajaran Inkuiri Untuk Menigkatkan Hasil Belajar. Jurnal Ilmiah Sekolah Dasar. Vol.1 (1) pp. 20-29.

Priansa,Donni.J.2017.Pengembangan Startegi dan Model Pembelajaran (Inovatif,Kreatif dan Prestatif Dalam Memahami Peserta Didik.Bandung : CV Pustaka Setia.

Purniadi. 2017. Penerapan Pendekatan Inkuiri Pada Mata Pelajaran IPA Untuk Mengembangkan Karakter Siswa Di SD 01 Kota Bangun, Ojs.Uniskabjm.ac.id.Vol 3 (1).

Roni Wahyuni, Hikmawati, Muhammad Taufik. 2016. Pengaruh Model Pembelajaran Inkuiri Terbimbing dengan Metode Eksperimen terhadap Hasil Belajar Fisika Siswa Kelas XI IPA SMAN 2 Mataram. Jurnal Pendidikan Fisika dan Teknologi (ISSN. 2407-6902) Volume II No 4, Oktober 2016 : 164-169

Rostiyah.2012.Strategi Belajar mengajar.Jakarta: PT Reneka Cipta.

Sudjana. 2005. Metode Statistika. Bandung: Tarsito

Sukardi. 2003. Medotologi penelitian Pendidikan. Yogyakarta ; Bumi Aksara

Suryobroto. 2009. Proses Belajar dan Mengajar di Sekolah, Jakarta: Rineka Cipta.

Wardoyo, S.M .2015. Pembelajaran Konstruktivi me teori dan Aplikasi Pembelajaran

Wahab Jufri, 2013.Belajar dan Pembelajaran Sains, Bandung : Reka Cipta

Wina Sanjaya. 2006. Strategi Pembelajaran Berorientasi Standar Proses Pendidikan. Jakarta : Kencana 